Doutora em Comunicação e Semiótica pela PUC-SP e membro do Centro de Pesquisas Sociossemióticas (CPS) da mesma instituição. Docente na Faculdade de Comunicação, Artes e Design do Centro Universitário Nossa Senhora do Patrocínio (CEUNSP), em Salto, São Paulo.

E-mail: paulapiotto@terra.com.br

\title{
Do corpo político à política no corpo
}

\author{
From the political body \\ to the politics in the body
}

[resumo] 0 corpo do político e a política na carne do corpo político são o cerne deste estudo, que tem como foco a presidente Dilma Rousseff e descreve uma trajetória que parte do retrato na galeria dos presidentes da República e culmina num ato flagrante nas páginas da mídia impressa. De um lado estão os corpos políticos colocados em circulação de modo a fomentar o espetáculo midiático, de outro, a possibilidade de ruptura e a depreensão de outro sentido.

corpo; política; semiótica; interação.

[abstract] The body of the politician and politics in the flesh of the political body are in the core of this study, which focuses on president Dilma Rousseff and describes a trajectory that starts at the picture in the republican presidents gallery and culminates in a flagrant act in the pages of printed media. On one side are political bodies placed in circulation in order to enhance the media spectacle, on the other, the possibility of rupture and the apprehension of another sense.

[keywords] body; politics; semiotics; interaction. 
Em meio a insígnias, faixas, barbas, bigodes, fardas, ternos, casacas, colarinhos, gravatas, rostos tesos, semblantes plácidos, sorrisos, meios sorrisos, sorrisos largos e sorriso algum, eis os corpos presentes na galeria dos presidentes da República Federativa do Brasil do $22^{\circ}$ ao $29^{\circ}$ períodos de Governo Republicano. Os homens da República são, na maioria, advogados, seguidos por um número significativo de militares marechais e generais, um médico, um engenheiro, um sociólogo, um metalúrgico e uma economista. Nesse caso, mais importante é ser economista, embora o fato de ser mulher tenha sido evidenciado durante toda a campanha eleitoral de Dilma Rousseff, enfatizando o valor de ser mulher e a primeira a ocupar esse escalão do governo. Mas que tipos de "presença" constituem esses corpos na galeria?

Em Flagrantes delitos e retratos, Eric Landowski (2004) postula que a "espetacularização generalizada" consiste num fazer recorrente do discurso publicitário comercial e da comunicação política, ambos pautados numa visibilidade que objetiva a construção de um simulacro do "dizer verdadeiro". 0 estudioso explica que as imagens disseminadas pelas mídias intermedeiam a relação do sujeito com o real e que o advento da reprodução técnica serviu para consolidar essa noção de realidade, ou seja, a crença na objetividade das imagens mediatizadas. Nesse viés, e sempre de acordo com esse semioticista, o que deveria ser o espaço de discussão pública dá lugar à "propagação de um manto de imagens que lustra e unifica uma visão de mundo, à qual somos instigados a aderir, a crer, a aquiescer, pelo menos com o olhar" (LANDOWSKI, 2004, p. 32). Com o que, a análise das ideologias circulantes e dos discursos subordina-se à "cobertura visual que em todos os domínios mediatiza doravante nossa apreensão do mundo" (LANDOWSKI, 2004, p. 32).

Sustentado por investigações precedentes ${ }^{1}$ e tendo como ancilar um corpus de imagens pertencentes à iconografia do discurso publicitário e do noticiário político veiculados nas mídias, Landowski (2004) defende que, diferentemente da comunicação publicitária, a análise da informação política demanda certo refino. 0 estudioso esclarece que, no domínio da publicidade, a colocação em cena de corpos, aos quais ele irá se referir como "quase puros 'corpos de papel"', obedece a um fazer estratégico que:

(...) consiste em associar de maneira quase sistemática à encenação das mercadorias realmente propostas a de corpos imaginariamente ofertados. Mas entendemos que isso encontra sua razão de ser na esperança de que os receptores transfiram para aquelas o valor que não podem não reconhecer nos últimos, a saber, o de objetos de gozo fantasioso (LANDOWSKI, 2004, p. 33).

Pois as articulações da comunicação publicitária que engendram os sujeitos nesse prazer imaginoso corroboram o reencantamento do mundo ou alguma forma de gozo nesse modo de estar em relação com o outro, o que, no entender desse semioticista, é a condição pressuposta e limítrofe para o ingresso no território do político.

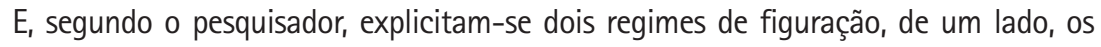
"corpos sem nome, mas desejantes" dos textos imagéticos da publicidade, do outro, os "atores reconhecíveis, mas quase sem corpos" (LANDOWSKI, 2004, p. 36), quando esses mesmos textos têm como enfoque a política. Pois, tendo em conta que as imagens mediatizadas de corpos políticos não são necessariamente vinculadas ao desejo, Landowski (2004, p. 34) lança mão de "'ilustrações' articuladas ao conteúdo da 'informação', cenas 'ao vivo' ou documentos de arquivos, fotos saídas de reportagens ou (...) retratos de personalidades políticas mais ou menos conhecidas e que poderíamos, se surgir a ocasião, encontrar pela frente", a fim de investigar quais tipos de lógica e de estratégias articulam os discursos midiáticos "na construção da imagem do político e dos políticos" (LANDOWSKI, 2004, p. 36).

Depois de esquadrinhar imagens de corpos políticos coletados das mídias, Landowski $(2004$, p. 31) constrói uma tipologia na qual descreve "as quatro dimensões específicas" do retrato, a saber: mimética, cosmética, hermenêutica e estética. 0 pesquisador valida a proposição de que "sob o nome de 'discurso público' - publicidade comercial e comunicação política conjuntas uma à outra para formar um único e mesmo discurso abrangente -, encontra sua realização numa imagem comum, em que nada mais permite distingui-los" e sua investigação culmina em ratificar a 
"consagração da abordagem publicitária como princípio geral de visão do mundo e, correlativamente, cosmetização do político" (LANDOWSKI, 2004, p. 67).

É sob o amparo das postulações elencadas em Landowski (2004) e inicialmente num tipo de retrato bastante elementar, contando que seja possivel se expressar dessa forma, mas elementar no sentido de que ele se reduz ao essencial do sujeito retratado, que o presente artigo opta por uma testagem. Em efetivo, tendo como exemplário figurações de Dilma Rousseff, trata-se aqui de experimentar a tipologia proposta por Landowski, com o objetivo especifico de compreender como se pode depreender a política a partir do retrato do corpo político.

0 rosto de uma mulher de fisionomia jovem, cabelos curtos, portando óculos de lentes espessas, camisa xadrez e sem investimentos que acentuem sua feminilidade, ocupa o centro do retrato em preto e branco sobre o fundo cinza. Numa tomada que se estende até parte do tronco, ela segura sobre o busto uma plaqueta com a inscrição numérica 3023 e, privado de qualquer outra marca que possa guiar seu olhar, cabe ao enunciatário reconhecer nesse retrato o sujeito "fichado" pela polícia. Numa outra situação, quando essa mesma imagem aparece na capa de Época, a menos que o texto explique que se trata de "documentos inéditos" de uma ativista contra o regime militar e que essa jovem é Dilma Rousseff, então candidata à presidência da República, nada, ou quase nada, nesse retrato pode desvelar sua atuação política. Imagens dessa natureza, na qual invariavelmente o fotografado ostenta um número sobre o peito, servem para registrar as marcas de identificação de um rosto, nesse caso "aquilo com o que um sujeito 'parece' depende menos do que ele 'é' que da maneira como ele é representado" (LANDOWSKI, 2004, p. 41). No papel fotográfico, não há nada além das manchas de ferrugem dos grampos agora ausentes, que, nota-se, serviram para fixá-lo em algum documento, e do semicírculo de um carimbo, o qual possivelmente servia para indicar o órgão expedidor responsável por tal registro. 0 que se vê são [110] apenas marcas temporais do referido "passado de Dilma", que, segundo a chamada verbal, ela prefere esquecer e o retrato não registra.
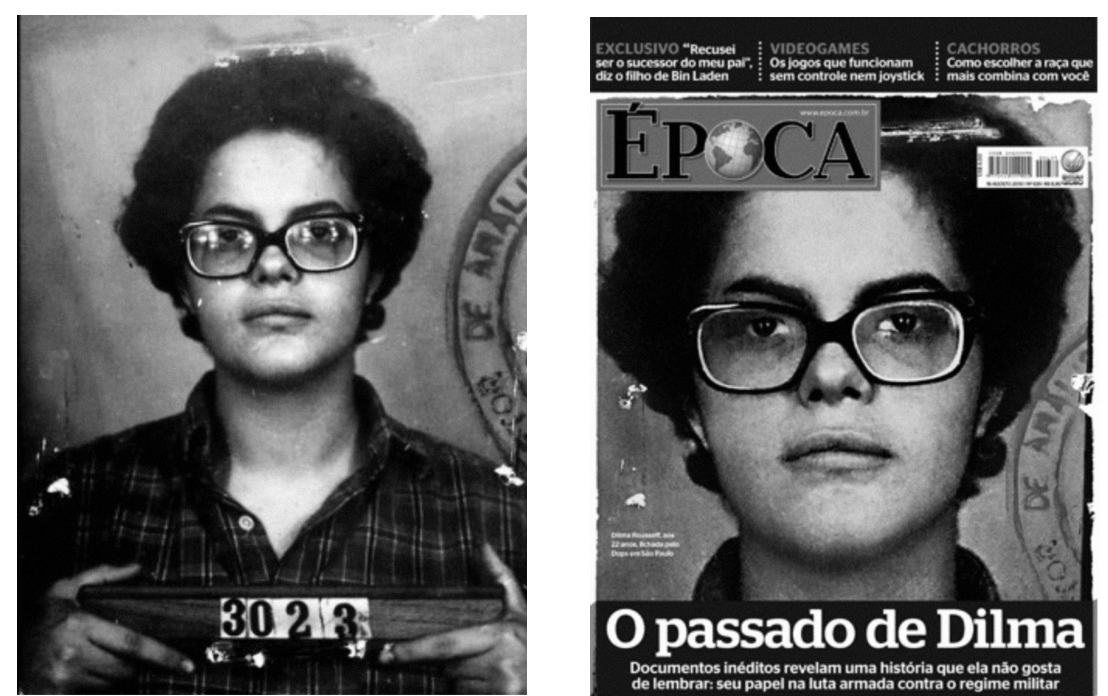

Fig. 1: 0 olhar fixo de uma mulher muda num corpo de papel e um conjunto de marcas identitárias, cujo nome é Dilma Rousseff, na página da revista; o reconhecimento do sujeito e a impossibilidade de desvelar o passado da ex-militante política, eis o corpo objeto na dimensão mimética do retrato. ${ }^{2}$

Talvez seja o caso de substituir a imagem e deparar-se com uma Dilma Rousseff "atualizada" no retrato. A mulher madura, que mantém os cabelos curtos, mas evidentemente modelados numa escova, agora usa brincos e colar, delineia os olhos e apara as sobrancelhas. Ela abandonou os óculos e é possivel que os tenha trocado por lentes de contato ou se submetido a alguma cirurgia de correção, procedimento da mesma natureza que deu outra aparência ao seu nariz. Trata-se de arranjos como o que permitiu, por exemplo, colocar a estrela do PT como pingente do colar que ela leva no pescoço. Essa imagem, também em preto e branco, da mulher candidata à presidência, agora com grande investimento na sua feminilização e emoldurada no vermelho do 
Partido dos Trabalhadores, dá a ver que o sujeito moveu a cabeça e que está observando algo que se passa alhures, talvez o futuro. A imagem em preto e branco corrobora uma marca temporal e espacial em ambas as imagens. No primeiro caso (Fig. 1), uma embreagem enunciativa é a estratégia utilizada pelo enunciador para evidenciar "o passado de Dilma", com o que se produz o efeito de sentido de delação. Posteriormente, o texto fala de mudança (Fig. 2), mas, no retrato em preto e branco, é no gesto de Dilma, que se presentifica nesse ato de olhar alhures, que está a concomitância. Significa que o presente no qual se enuncia que "A realidade mudou, e nós com ela" está em relação a um futuro figurativizado no cromatismo vermelho que emoldura Rousseff e dá a ver essa realidade. De acordo com o que ensina Landowski, "somente podemos reconhecer um 'sujeito' na imagem de um indivíduo a partir do momento em que o vemos entrar em relação com um 'objeto' qualquer, quer se trate do mundo que o envolve, de um parceiro, ou até, no limite, simplesmente dele próprio" (LANDOWSKI, 2004, p. 49), por isso é possível depreender a realidade por meio desse retrato.

A essa altura, para que se possa falar com fundamento desses dois retratos de Dilma Rousseff, convém retomar as descrições de Landowski, pois é ele quem ensina que a dimensão mimética do retrato é da ordem da identificação e do tornar factível o reconhecimento do modelo fotografado. Nesse caso, o que está em jogo é a semelhança entre o sujeito e a imagem retratada, portanto, sob a diretriz de identificar e de reconhecer o retratado, está o que esse semioticista denomina "clichê antropométrico". Pode-se dizer que é exatamente isso que Época faz ao estampar essa efeméride de Dilma, afinal o que está no retrato documental são as marcas fisionômicas de uma jovem que lutou contra o regime militar. Mas o que pode revelar esse corpo que tinha a ex-militante?

No desenvolvimento do ensaio em questão, Landowski recupera a figura do "camaleão" para falar do sujeito que se transforma, pelo menos no nivel da manifestação, quer seja por interesse ou por conveniência. Então, esse pesquisador argumenta que "somos todos, mais ou

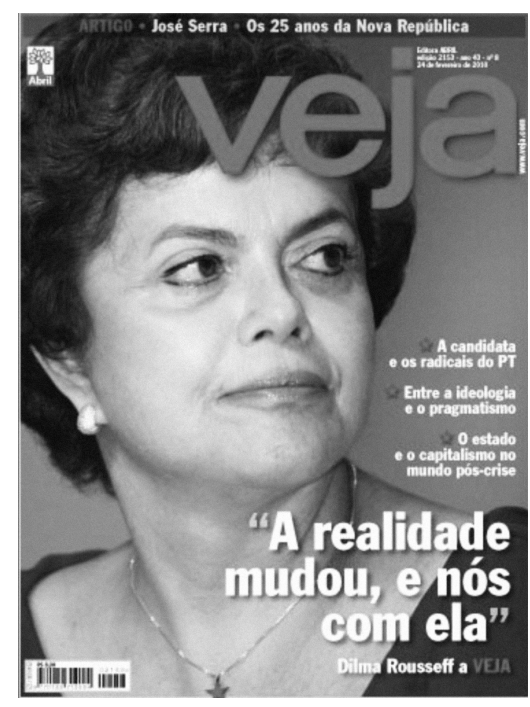

Fig. 2: A realidade muda e está plasmada no corpo que, "num sopro de vida", desvela-se numa presença a caminho da construção de um modelo de Dilma Rousseff candidata a presidente, eis o corpo do sujeito na dimensão cosmética do retrato e não mais na mimética. menos, 'camaleões', isto é, mutantes na superfície (quer queiramos quer não) à medida que nos tornamos nós mesmos" (LANDOWSKI, 2004, p. 39), e é precisamente isso que está dito na contemporaneidade de Veja na voz de Dilma. Contudo, o que mais é possível desvelar a partir do "corpo que tem" a candidata retratada na capa dessa revista?

Colocadas as figuras 1 e 2 em relação, observa-se que a mudança no nível mais superficial é inquestionável. Contudo, o que a define não se limita ao reducionismo diacrônico da jovem guerrilheira à candidata a presidente. Dada a semelhança entre Dilma, sujeito capturado pelas forças da repressão militar, e a imagem da sua constituição fisionômica, o que a torna passível de reconhecimento na ficha criminal, pode-se afirmar que a imagem de Dilma na capa de Época inscreve-se na dimensão mimética do retrato. Mas se "uma boa foto de identidade é aquela que permite associar com o mínimo de erros um nome próprio a um conjunto de traços fisionômicos necessários e suficientes para reconhecer o indivíduo portador desse nome" (LANDOWSKI, 2004, p. 39), a figura de Dilma na capa de Veja ratifica a mudança. E a fundamentação sobre o traço distintivo entre os dois retratos está cingida na proposição de uma variante "pseudo-oficial", sobre a qual Landowski (2004, p. 59) explica, ensinando que: 
(...) [a variante pseudo-oficial] implica retificações cosméticas do modelo, mas as subordina exclusivamente às supostas expectativas da opinião. Estamos aqui bem próximos da construção das "imagens de marca" no âmbito da publicidade comercial e do marketing. Esse tipo de figuração alcança a difusão em massa na forma do "retrato eleitoral", tal como o vemos nos cartazes de campanha dos candidatos. Embora nesse plano certo grau de "feminilização" das silhuetas, expressões e atitudes seja certamente hoje uma estratégia em voga, essa parece ainda longe de substituir as receitas clássicas, essencialmente fundadas na procura do look sério.

Em suma, trata-se de um corpo em dois retratos, que, dispostos em relação um com o outro, remetem à dicotômica do passado versus o presente ou da manutenção versus a mudança, o que desvela um sentido de descontinuidade na manifestação e, possivelmente, de continuidade na imanência. Na figuração do primeiro (Fig. 1) não há indícios de que uma política do corpo possa ser depurada, o retrato tem características de fato "antropométricas"; no segundo (Fig. 2), é no mínimo curiosa a possibilidade de ver que os olhos de Dilma olham para um novo tempo. E assim como é implausivel que as marcas no retrato mimético permitam o reconhecimento da "identidade política", parece que o corpo na publicização eleitoral não está próximo de desvelar a política do corpo no retrato "pseudo-oficial", que é da "dimensão cosmética" e da ordem do não reconhecimento. No postulado de Landowski, o conceito de cosmetização da imagem do sujeito vai ao encontro das normatizações sociais, num arranjo que visa tornar a aparência do sujeito retratado convergente ao estatuto que ele ocupa na sociedade. Pelo que, com os retratos na galeria dos presidentes não é diferente, uma vez que eles são da ordem dessa última figuração, e a preposição de Landowski $(2004$, p. 48) sobre a função de cosmeticidade do retrato oficial é que:

(...) ele trabalha o "perfil" do sujeito retratado - o engrandece, o "embeleza" se quisermos, ou antes o normaliza - de maneira a tornar sua aparência tão conforme quanto possível a um cânone de representação da função ou do estatuto que ele assume na sociedade. Ao impor assim ao indivíduo um modelo identitário pré-concebido, espécie de traje prêt-à-porter no interior do qual ele deverá se deixar moldar, tal regime iconográfico reserva, por definição, um lugar apenas marginal para a exploração das singularidades individuais. É preciso de fato apagar tudo o que possa destoar na pessoa para que o personagem, elemento de uma classe - política, social, profissional ou outra -, possa entrar na galeria dos retratos que celebrará "oficialmente" sua memória (ou, em outra escala, segundo a tradição das boas famílias, no álbum ou nos porta-retratos decorativos nos ambientes da sala).

Por conseguinte, ao examinar os corpos políticos dispostos na galeria dos presidentes, obsenva-se que, ao contrário de seus antecessores, Fernando Henrique Cardoso optou pela visibilidade defronte os livros, ao passo que Lula e Dilma Rousseff escoIheram postar-se diante das colunas do Palácio da Alvorada. E, de fato, tem algum significado Dilma ter escolhido se abrigar na parte interna das colunas, ao passo que Lula optou por mostrar-se no lado externo. Ainda concernente à significação, observar que Sarney e Collor tenham preferido a casaca e o fundo cromático neutro, enquanto Itamar Franco tem a bandeira ao fundo e veste um terno convencional e, assim como Tancredo Neves, não porta faixa de presidente, concorre para uma análise que redunda nas variantes do retrato "cosmético". E sobre isso há precedente teórico, uma vez que:

No caso do retrato oficial, será tipicamente a biblioteca, motivo convencional até recentemente quase obrigatório (...), cujo papel é subli-

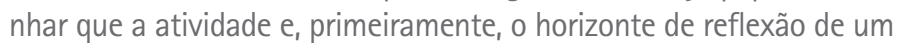
homem de Estado (ao menos no estilo "velha Europa") superam as peripécias da atualidade e se inscrevem na História... (LANDOWSKI, 2004, p. 49). 

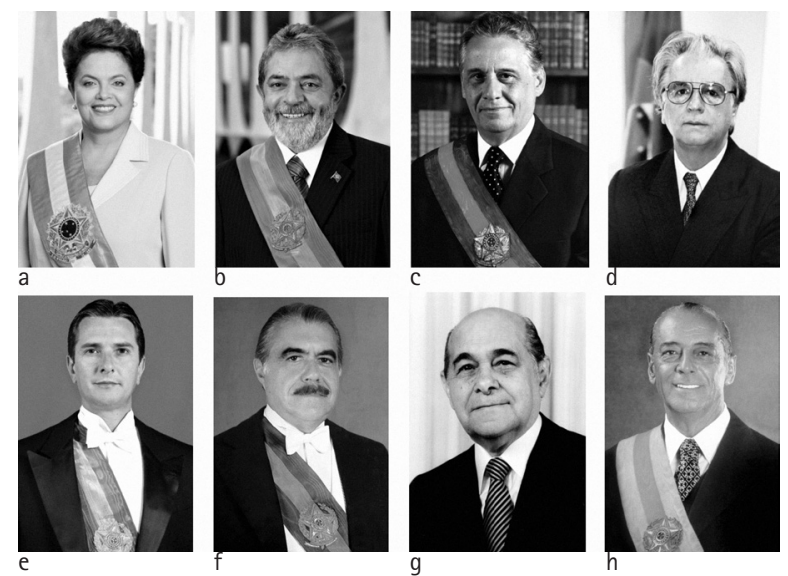

Acredita-se, todavia, que estes elementos são modos de visibilidade desses políticos, talvez insuficientes para uma elucubração sobre a política do corpo, mas que, por dar a ver a escolha desses sujeitos, desvelam seus valores. Nesse caso é Oliveira (1997, p. 237) quem ensina que:

Os objetos existem com um propósito, têm uma função, um uso, que igualmente os apresenta ou os impõe ao sujeito, os faz ser cobiçados, amados ou desprezados. Esse conjunto de traços é que define e coloca o objeto no mesmo nível que o sujeito, como um parceiro competente para a instauração entre ambos de uma relação eminentemente interativa. (...) Aquilo que o objeto faz sentir, sem que se perceba bem esse seu fazer, cria, pouco a pouco, entre sujeito e objeto, um elo mais ou menos forte em função da valoração que lhe é conferida e pela qual ele passa a ser considerado e apreciado. Mas o valorar, que aqui se dá em nível individual, está em conformidade com o sistema que organiza a vida coletiva; por isso, ele é circunstancial e historicamente marcado, 0 que imprime aos julgamentos de gosto um teor de temporalidade. Mais complexamente, nos julgamentos interatuam os valores que os estruturam, organizados, por sua vez, em conformidade com o sistema de valoração estabelecido no contexto sócio-econômico-político-cultural em que os sujeitos e as coisas se inserem e desempenham seus papéis.

A imagem apreendida sob essa perspectiva não oferece muitas possibilidades de investigação e remete, por exemplo, ao simulacro ambicionado por Getúlio Vargas, 0 qual pode ser apreendido no texto de sua carta testamento. Getúlio, na eminência de tornar-se um derrotado político, interrompe sua trajetória em detrimento da própria vida, o suicídio para preservação da memória, como se o percurso de um governante pudesse ser limitado a um retrato na galeria. Daí, as condições de postular nesta investigação que é "em ato" e no âmbito das "situações" que o corpo do político, quer seja o corpo que ele "tem" ou o corpo que ele "tinha", jovem ou antigo, vivo ou morto, dá lugar ao que o político "é", e isso significa dizer: dá lugar à política do corpo do político.

À guisa das considerações formuladas por Landowski, se as imagens dos sujeitos "em situação" na diretriz do retrato oficial são abalizadas pelas convenções sociais que moldam o sujeito retratado, nos "flagrantes delitos" as figuras estão em condições abertas, livres de estereótipos do gênero e do enquadramento dos cenários. E se a imagem "antropométrica" do criminoso opõe-se radicalmente aos arranjos cosméticos que solapam os "olhos esbugalhados diante da objetiva", o ato de surpreender um sujeito em transgressão implica posições que admitem, de um lado, o detrator, e de outro, o cúmplice. Eis, portanto, no nivel da enunciação, a relação intersubjetiva, na qual se colocam em ato, vis-à-vis, e em situação, corpo a corpo, governantes e governados. Cabe, nesse caso, a título de ratificação, recuperar a descrição explicativa de Landowski (2004, p. 49), que argumenta:

(...) a vocação que atribuímos hoje em dia à fotografia (profissional ou amadora) é, exatamente ao contrário, privilegiar, segundo a conhecida expressão de Cartier-Bresson, o "momento decisivo", isto é, a captura dos sujeitos "em situação". Na verdade, essa atenção dirigida aos elementos situacionais ou contextuais como componentes do sentido da imagem caracteriza não apenas o flagrante delito (na acepção que aqui conferimos ao termo), mas até mesmo o retrato oficial, ainda que em termos mais limitados em razão das convenções que o restringem. Um e outro se empenham, em geral, a captar o modelo em um contexto, 
freqüentemente colocado em segundo plano, suficientemente evocador para permitir situar, no tempo e no espaço, um mínimo de características pertinentes próprias ao universo do sujeito fotografado e, se for o caso, a seu campo de ação.

Concernente a isso, como ensina esse mesmo semioticista, "ao contrário do clichê antropométrico que, literalmente, 'tira a palavra' do sujeito - boca fechada e olhar fixo -, o flagrante delito (e em menor grau, conforme visto, o retrato oficial) coloca em cena 'sujeitos enunciantes', ou de forma geral corpos em estado de comunicação" (LANDOWSKI, 2004, p. 52). Então, defronte dos três corpos políticos (Fig. 4), o observador é capaz de surpreender e de se surpreender com situações tão adversas se comparadas às anteriores.

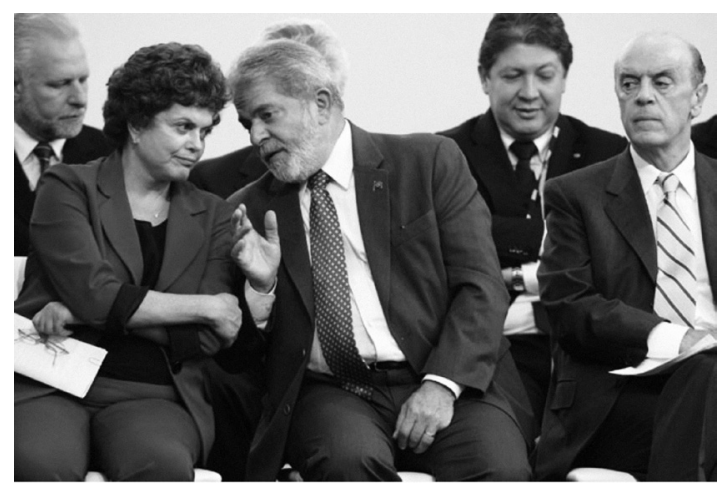

Fig. 4: Às boas maneiras aliam-se maneiras de ser do corpo; no flagrar esses sujeitos em ato, emerge a possibilidade de conhecimento, eis nesse "flagrante delito" a "dimensão hermenêutica" do retrato. ${ }^{5}$

Flagrar o presidente Lula conversando ao pé do ouvido com sua ministra-chefe da Casa Civil não é lá tão surpreendente; causa mais inquietação, e não necessariamente estranhamento, o olhar de ressaibo de José Serra, numa expressão que revela descontentamento com aquilo que vê. Esse é um episódio que acontece mais ou menos assim: um encontro que reúne políticos importantes, mas de facções distintas, uma situação que aparentemente requer, senão pompa, alguma circunstância, e, de repente, o primeiro homem do país infringe as regras das boas maneiras. Ou será que ele não aprendeu que não é de bom tom cochichar? Todavia, pior do que o ato transgressor é a situação de desconhecer o que confidencia a dupla política. Aliás, o sorriso irônico do sujeito que está sentado logo atrás denuncia o que, pelo menos para Serra, é digno de reprovação. E aí incomoda menos o ato de fofocar do que o seu teor, ou seja, 0 motivo do conchavo. Seria essa imagem delatora de uma conspiração política que se organiza com vistas a uma sucessão presidencial orquestrada quando Lula ainda está no governo? Agora, mais importante do que encontrar uma resposta, é a possibilidade de situar esse "flagrante delito" no que Landowski (2004, p. 50) denomina dimensão hermenêutica do retrato e dar destaque à observação do pesquisador, ao dizer que:

(...) é sobretudo quando a imagem captura o sujeito em relação com o outro que ela apresenta um interesse particular do ponto de vista politico, ao menos se admitimos que na raiz de todo comportamento político há, antes de tudo, uma determinada maneira de experimentar a si mesmo na presença do outro e, conseqüentemente, de dirigir-se a ele.

A seara política é cheia de meandros, ainda mais no Brasil, que, além de ser "gigante pela própria natureza", é um território que carrega não só o estigma, mas a herança cultural da colonização. 0 exercício do poder numa República Federativa Democrática Presidencialista, que esse país é, implica a política na esfera de uma nação que conserva a autonomia de várias lideranças políticas nos estados, e isso constitui uma federação. Numa democracia, e o sistema político brasileiro nem sempre foi esse, o chefe de Estado é eleito pelo povo, e, como a autoridade emana desse conjunto de cidadãos, é o povo quem governa. No presidencialismo, a ação predominante no governo cabe ao presidente que foi eleito representante do povo. Os três poderes, Executivo, Legislativo e Judiciário, pela Constituição Brasileira, são independentes e harmônicos entre si, mas devem controlar uns aos outros a fim de obter o equilibrio. 
No que tange ao equilíbrio das forças políticas, o corpo de Dilma Rousseff sendo atingido por uma espada (Fig. 5) desvela exatamente o contrário, pois, se existem "atores reconhecíveis, mas quase sem corpo" (LANDOWSKI, 2004, p. 36), definitivamente, não é isso o que acontece nessa imagem. Ao vislumbrar esse desequilibrio na esfera do poder, o observador sente com o próprio corpo a cadência ritmada na imagem do corpo de Dilma Rousseff sendo perpassado por uma lâmina. Um "drama" que envolve, antes, sentir a ponta do objeto tocar e perfurar suas costas e o metal deslizar na sua carne, depois, a dor dilacerante a ponto de fazê-la perder os sentidos e, no momento seguinte, apostar que esse corpo que se dá a ver declinando, estará tombado no chão. É pérfido, sem dúvida, o ato de apunhalar pelas costas, mas o requinte dessa imagem é a identidade velada do algoz. Velada e desvelada, porque na medida em que só é dado a ver parte do braço, nele se nota a farda do sujeito que desferiu num só golpe a sentença de morte. Ato conspirativo, diametralmente oposto ao observado na figura 4, como se agora fosse o momento da vingança ou justiça de antigos poderes. Pouco importa: é dessa forma, com uma estaca cravada no coração, que se exterminam não só os vampiros, mas também as bruxas e toda ordem de criaturas indesejáveis.

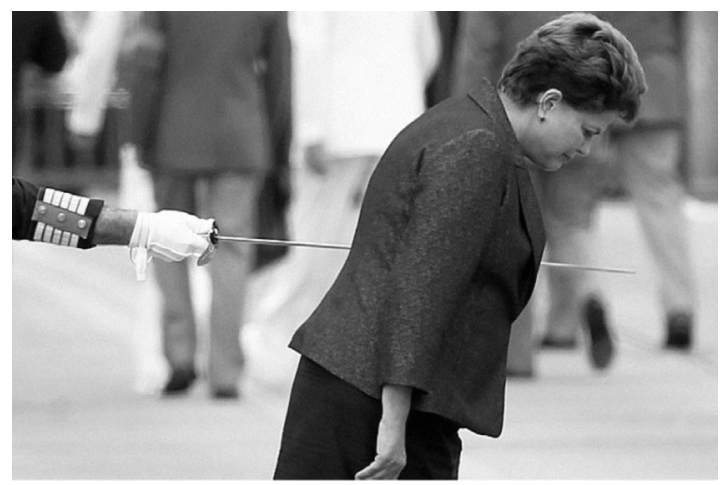

$$
\begin{aligned}
& \text { Fig. 5: Na coalescência dos } \\
& \text { sentidos, ver o corpo no } \\
& \text { corpo e sentir a ruptura da } \\
& \text { continuidade no movimento } \\
& \text { ritmado dessa imagem que } \\
& \text { permite "ouvir o silêncio" } \\
& \text { e imaginar a luva ilibada } \\
& \text { borrar-se de sangue. Eis, na } \\
& \text { deformação da realidade, } \\
& \text { a experiência estésica na } \\
& \text { dimensão estética do retrato. }{ }^{6}
\end{aligned}
$$

Na aproximação estésica entre o enunciatário e o corpo de Dilma Rousseff, percebe-se também o movimento célere no segundo plano dos sujeitos que batem em retirada. Seriam eles corpos omissos? Na continuidade ritmada dessa imagem, concomitante ao tombo do corpo será sentido o movimento da espada sendo retirada e, na visão turva do segundo plano desfocado, será sentido o profundo silêncio que se instala quando se é tocado por esse ato inesperado. Desse modo, e de novo, mais importante do que encontrar respostas agora, é o dar prova de que se pode sentir por meio da imagem.

Esse tipo de retrato se enquadra no que Landowski denomina de dimensão estética e deve ser observado que os termos cosmético e estético, os quais correntemente acabam sendo empregados com o mesmo significado, tem acepções distintas no que concerne à tipologia construída por esse semioticista. Enquanto os retratos na sua dimensão cosmética dão conta do revestir dos modelos de forma a torná-los "ilustres" desconhecidos, na dimensão estética, a prática do retrato destaca-se pela plástica. Trata-se nesse caso da dimensão poética, sobre a qual Landowski (2004, p. 64), na sua descrição analítica, pontua que "além do flagrante delito (pois aqui não há nada de transgressivo a ser observado), é verdadeiramente um 'momento decisivo' que foi fixado: momento de graça em que o fazer poético alcança a dimensão poética". 0 retrato estético é dotado de uma ordenação rítmica e pode ser sentido estesicamente, tal qual o que se experimenta diante de um corpo golpeado (Fig. 5). Ao ser inserido, torna-se partícipe, se está em condições de aplaudir, deplorar ou negligenciar, como se nota que alguns já o fizeram, então, o extraordinário nos retratos que ocupam essa dimensão é o fato de eles não passarem despercebidos, o que redunda da "combinação de elementos que, além dos componentes plásticos e rítmicos do enunciado-imagem, fazem intervir a dimensão enunciativa" (LANDOWSKI, 2004, p. 64-65).

Diante do explanado nos parágrafos subsequentes, cujas breves análises dos retratos de Dilma Rousseff serviram para sumarizar o postulado em Flagrantes delitos e retratos, cabe aqui recuperar que a consideração de Landowski é sobre a cosmetização do político e a consequente generalização da visão de mundo que acomoda os sujeitos na vala comum. Daí que a maior probabilidade de depreender a política do corpo político é examinando os "flagrantes delitos" e a "dimensão poética" dos retratos colocados em circulação nas mídias. Landowski (2004, p. 52) argumenta que 
"a iconografia política simplesmente renunciou a tematizar o 'poder como drama'", mas ele também ensina que:

\begin{abstract}
Se o jornalismo tem por missão, entre outras, nos ajudar a melhor conhecer nossos representantes e dirigentes, compreendemos a partir desses elementos por quais razões de fundo a fotografia ocupa hoje tanto espaço inclusive na parte redacional dos jornais - um espaço (os repórteres fotográficos com razão são os primeiros a sublinhá-lo) que não mais pode ser considerado como simples "ilustrações" subordinadas à "informação". É que a imprensa dispõe hoje em dia de recursos técnicos que lhe permitem não apenas nos informar, pela escrita ou pela fala, sobre as "posições" políticas que exibem os homens de poder. Graças à fotografia, mesmo a imprensa "escrita" está em condições de captar, além disso, e de nos fazer sentir diretamente as "posturas" - também elas políticas, mas em um nível mais profundo - que eles adotam corporalmente. E com esse propósito, a imagem é sem nenhuma dúvida o melhor instrumento tanto de investigação quando de demonstração (LANDOWSKI, 2004, p. 52).
\end{abstract}

Por isso, este breve estudo postula não confinar a análise das "posturas políticas" ao retrato na parede ou à esteira da "programação" das instituições. São pressupostos contrários a esse prisma de visão que fomentam esta argumentação e instigam a uma aproximação capaz de romper a perspectiva reducionista, manipuladora e programada do político e dos políticos no "jogo enunciativo". Pensando assim, talvez, antes de o corpo de Dilma tocar o solo, seja possível compreender que o poder do soberano congrega o poder de outros sujeitos, que política e político não são unívocos e que governar consiste num fazer estratégico; de modo que a morte do corpo pode constituir um mecanismo de permanência, ao menos política, e a interrupção da vida, na [116] esfera política, não significa necessariamente a morte do corpo. Afinal, subsistir acaba se tornando uma experiência política.

\title{
NOTAS
}

[1] Sobre isso Landowski (2004, p. 35) consta uma remissão do autor, em forma de nota, às obras A sociedade refletida (1992) e Presenças do outro (2002).

${ }^{[2]}$ Foto de Dilma Rousseff no arquivo do Dops - Departamento de Ordem Política e Social. Fonte: Época, 16 ago. 2010.

${ }^{[3]}$ Fonte: Veja, 24 fev. 2010. Disponível em: <http://veja.abril.com.br/acervodigital/home.aspx>. Acesso em: 5 jul. 2013.

${ }^{[4]}$ a) Dilma Rousseff (1/1/2011); b) Luiz Inácio Lula da Silva (1/1/2007 a 1/1/2011) segundo mandato e (1/1/2003 a 1/1/2007) primeiro mandato; c) Fernando Henrique Cardoso (1/1/1999 a 1/1/2003) segundo mandato e (1/1/1995 a 1/1/1999) primeiro mandato; d) Itamar Franco (2/10/1992 a 1/1/1995); e) Fernando Collor de Mello (15/3/1990 a 2/10/1992); f) José Sarney (15/3/1985 a 15/3/1990); g) Tancredo Neves (presidente eleito e não empossado); e h) João Figueiredo (15/3/1979 a 15/3/1985). Fonte: Disponivel em: <http://www.presidencia.gov.br/info_historicas>. Acesso em: 5 jul. 2013.

${ }^{[5]}$ Foto: Epitácio Pessoa/Agência Estado. Disponivel em: <http://g1.globo.com/Noticias/Politica/0 "MUL15135395601,00-DILMA+TEM+DOS+VOTOS+DE+QUEM+RECEBE+BOLSA+FAMILIA+DIZ+DATAFOLHA.html>. Acesso em: 5 jul. 2013.

${ }^{[6]}$ Foto:Wilson Júnior/Agência Estado. Disponivel em: <http://blogs.estadao.com.br/radar-politico/2011/08/23/ estadao-desmente-foto-montada/>. Acesso em: 5 jul. 2013.

\section{REFERÊNCIAS}

LANDOWSKI, E. A sociedade refletida: ensaios de sociossemiótica. São Paulo: Educ/Pontes, 1992. . Presenças do outro. São Paulo: Perspectiva, 2002.

Flagrantes delitos e retratos. Galáxia. Revista do Programa de Pós-Graduação em Comunicação e Semiótica da PUC-SP. São Paulo: Educ, v. 4, n. 8, p. 31-69, out. 2004. 